\title{
The Role of Unemployment in the Rise in Alternative Work Arrangements
}

\section{Citation}

Katz, Lawrence F., and Alan B. Krueger. 2017. The Role of Unemployment in the Rise in Alternative Work Arrangements. American Economic Review 107, no. 5: 388-392.

\section{Permanent link}

http://nrs.harvard.edu/urn-3:HUL.InstRepos:41288108

\section{Terms of Use}

This article was downloaded from Harvard University's DASH repository, and is made available under the terms and conditions applicable to Other Posted Material, as set forth at http:// nrs.harvard.edu/urn-3:HUL.InstRepos:dash.current.terms-of-use\#LAA

\section{Share Your Story}

The Harvard community has made this article openly available.

Please share how this access benefits you. Submit a story.

\section{Accessibility}




\title{
INCOME INEQUALITY AND INCOME RISK IN THE 21ST CENTURY
}

\section{The Role of Unemployment in the Rise in Alternative Work Arrangements}

\author{
By Lawrence F. Katz and Alan B. Krueger*
}

Much evidence indicates that the traditional nine-to-five employee-employer relationship is in decline. Although comprehensive, high-frequency data on US work arrangements are not available, the trend appears to have begun before the advent of the platform economy and the spread of online gig work. We have updated the Bureau of Labor Statistics' (BLS) Contingent Worker Supplement (CWS) to the Current Population Survey (CPS) by adding a similar CWS survey to the RAND American Life Panel (ALP) in 2015 (henceforth RAND-CWS), and found that the share of the workforce engaged in an "alternative work arrangement" on their main job, such as working as a self-employed freelancer or working for a contract firm that contracts out employees to other companies, has grown from 10.7 percent in 2005 to 15.8 percent in 2015 (Katz and Krueger 2016). Additionally, Internal Revenue Service (IRS) data show that the share of workers reporting Schedule C income (i.e., income from self-employment) rose in the 1980s, stabilized in the 1990s, and rose again in the 2000s. From 1979 to 2014, the share of workers with Schedule C income nearly doubled, from 8.7 to 16.5 percent of the workforce.

A variety of explanations have been posited for the rise of alternative work arrangements, including: a fissuring of the traditional workplace by companies seeking to avoid rent sharing

* Katz: Department of Economics, Harvard University, Cambridge, MA 02138 (e-mail: 1katz@harvard.edu); Krueger: Department of Economics, Princeton University, Princeton, NJ 08540 (e-mail: akrueger@ princeton.edu). We are extremely grateful to David Cho and Kevin DeLuca for excellent research assistance.

${ }^{\dagger}$ Go to https://doi.org/10.1257/aer.p20171092 to visit the article page for additional materials and author disclosure statement $(\mathrm{s})$. and reduce regulatory burdens in the face of external market increases in skill differentials and wage inequality that raise the costs of compensation compression within a single employer (Weil 2014); technological changes that have standardized work and reduced monitoring and supervisory costs; a demographic shift toward an older workforce with older workers more likely to be self-employed; and a weak labor market leaving workers with little bargaining power and few options for traditional employment.

In this paper, we focus on the last explanation, the impact of weak labor markets and high joblessness. To do so, we examine the extent to which the experience of unemployment raises the likelihood that workers transition to an alternative work arrangement as opposed to a traditional employment relationship. Specifically, we link the February 2005 CPS-CWS to the February 2004 CPS and link the October-November 2015 RAND-CWS to earlier waves of the ALP from February, March, and April of 2013. We find that workers who suffered a spell of unemployment are 7 to 17 percentage points more likely than observationally similar workers to be employed in an alternative work arrangement when surveyed 1 to 2.5 years later.

We uncover little evidence that cyclical forces-and the 2008-2009 Great Recession in particular-played an important role in the growth of alternative work arrangements over the past few decades. In addition to the micro evidence on individual's unemployment histories, we find from aggregate time-series analyses that the rise in the share of workers with Schedule C income or employed by temporary help agencies in recent decades is dominated by secular trends rather than cyclical factors. Our findings lend support for the view that secular forces, such as rising inequality and 
technological changes causing incentives for a fissuring of workplaces, are responsible for most of the increase in alternative work arrangements.

\section{Data}

Two longitudinal datasets on workers' unemployment histories and subsequent experience working in alternative work were created from the 2005 CWS and the 2015 RAND-CWS. To create longitudinal data from the CPS-CWS, we applied Rothstein's (2011) algorithm to match individuals in the February 2004 CPS to the February 2005 CPS-CWS. ${ }^{1}$ We first created an initial person-specific identifier for each individual using the household identifier, household identification number, person line number, and state code. Next, we linked respondents from the February 2004 and February 2005 CPSs by their person-specific identifiers. Lastly, we attempted to identify and exclude respondents who shared the same person identifier but are actually different individuals by searching for discrepancies in their observable characteristics, such as gender, race, age, and educational attainment.

Only a subset of individuals (those in rotation groups 5, 6, and 7) who participated in the February 2005 CPS-CWS were surveyed in the February 2004 CPS. (Rotation group 8 was not given the 2005 CWS.) We were able to match 14,090 workers (representing 65 percent of those eligible to be matched) from the 2005 CPS-CWS to their February 2004 data.

The RAND ALP consists of a rotating panel of respondents who are regularly surveyed over the Internet. We attempted to link the 2,194 workers in the October-November 2015 RAND-CWS (Survey \#441) to the RAND ALP "Effects of the Financial Crisis" surveys conducted in February, March, and April 2013 (Surveys \#328, 332, and 335) using the unique person identifier ("prim_key") in the ALP files. The Financial Crisis surveys included questions on unemployment and self-employment status two-and-a-half years before the RAND-CWS was conducted. Not every CWS respondent participated in the earlier surveys, and some participated in multiple surveys. ${ }^{2}$ A total of 1,203

\footnotetext{
${ }^{1}$ Rothstein's (2011) Stata code is available at https:// berkeley.app.box.com/v/rothstein-replication-uiflows.

${ }^{2}$ We excluded 30 respondents who were assigned the same person identifiers in the Financial Crisis surveys and
}

respondents ( 55 percent) from the RAND-CWS could be linked to at least one wave of the Financial Crisis survey. For those who matched to more than one survey, we took data from the earliest month.

In the CPS and RAND longitudinal datasets, we restrict the samples to individuals who were in the labor force in both periods to examine how the experience of unemployment relates to transitions to alternative work arrangements. ${ }^{3}$ These restrictions yield samples of 13,387 workers for the CPS-CWS and 1,054 workers for the RAND-CWS. Alternative work consists of independent contractors and freelancers, workers who are contracted out from one company to work at another, on-call workers, and temporary help agency workers, following the BLS definition. Unemployment is measured by the BLS definition in the February 2004 CPS and by responding either "unemployed and looking for work" or "temporarily laid off" to the current employment status question in the 2013 RAND Financial Crisis surveys (Question LF001) $!^{4}$

\section{Longitudinal Estimates}

Table 1 reports logit models using the longitudinal CPS data, where the dependent variable equals 1 if the worker was employed in an alternative work arrangement in 2005 and 0 if he or she was employed in a traditional work arrangement in 2005. The explanatory variable of interest is an indicator for whether the worker was unemployed 12 months earlier, and the coefficients represent marginal effects on the probability of being in alternative work. Column 2 includes demographic variables and educational attainment. Column 3 adds a dummy variable indicating self-employment status in February

RAND-CWS but reported obvious discrepancies in gender, race, age, or educational attainment from 2013 to 2015.

${ }^{3} \mathrm{~A}$ further restriction involves age: the linked CPS-CWS dataset includes individuals 17 and older in 2005, and the linked RAND-CWS data contains individuals 21 years and older in 2015.

${ }^{4}$ The unemployment rate in the linked CPS sample in February 2004 was 2.9 percent, substantially below the 6.1 percent official unemployment rate that month. The discrepancy arises because those who could be matched across CPS surveys had lower unemployment in February 2004 than those who could not be matched. The unemployment rate in the linked RAND-CWS sample from February-April 2013 was 5.1 percent, also below the comparable BLS rate of 7.6 percent. 
Table 1-Marginal Effects from Logit Model of Being in Alternative Work Arrangement Conditional on FEBRUARY 2004 ChaRACTERISTICS

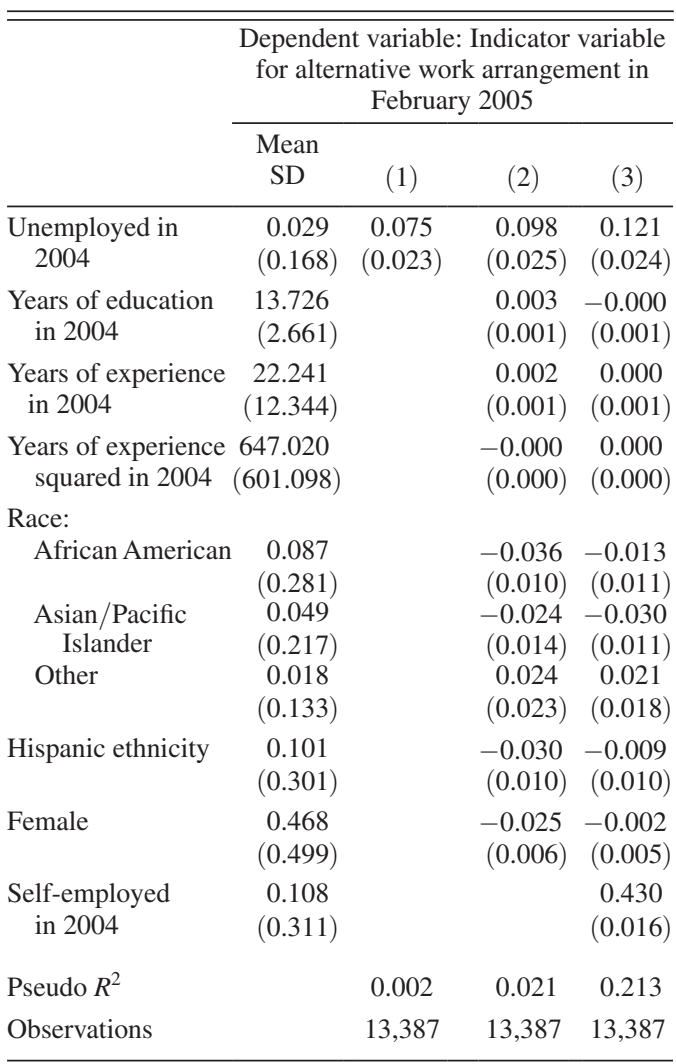

Notes: Sample represents individuals aged 17 years and older as of February 2005. Mean of dependent variable is 0.099. Logistic regressions are weighted using final weights from the February 2004 Current Population Survey.

Source: Current Population Survey (February 2004 Basic Monthly Data and February 2005 Contingent Worker Supplement).

2004 to partially control for working in an alternative work arrangement in the base period. Table 2 reports corresponding estimates using the matched 2013-2015 RAND-CWS sample.

Workers who suffer a spell of unemployment are significantly more likely to be employed in alternative work a year later in all of the models in Table 1, and including more control variables increases the size of the coefficient on unemployment. The magnitude of the coefficient on unemployment in column 3 indicates that workers who become unemployed are 12 percentage points more likely to be employed in an alternative work arrangement a year later than are
Table 2-Marginal Effects from Logit Model of Being in Alternative Work Arrangement Conditional on FEBRUARY-APRIL 2013 CHARACTERISTICS

\begin{tabular}{|c|c|c|c|c|}
\hline & \multicolumn{4}{|c|}{$\begin{array}{l}\text { Dependent variable: Indicator variable } \\
\text { for alternative work arrangement in } \\
\text { October-November } 2015\end{array}$} \\
\hline & $\begin{array}{l}\text { Mean } \\
\text { SD }\end{array}$ & (1) & (2) & (3) \\
\hline $\begin{array}{l}\text { Unemployed in } \\
2013\end{array}$ & $\begin{array}{c}0.051 \\
(0.221)\end{array}$ & $\begin{array}{c}0.068 \\
(0.069)\end{array}$ & $\begin{array}{c}0.117 \\
(0.073)\end{array}$ & $\begin{array}{c}0.173 \\
(0.069)\end{array}$ \\
\hline $\begin{array}{l}\text { Years of education } \\
\text { in } 2013\end{array}$ & $\begin{array}{l}13.999 \\
(2.400)\end{array}$ & & $\begin{array}{l}0.005 \\
(0.005)\end{array}$ & $\begin{array}{r}0.004 \\
(0.004)\end{array}$ \\
\hline $\begin{array}{l}\text { Years of experience } \\
\text { in } 2013\end{array}$ & $\begin{array}{c}21.158 \\
(12.593)\end{array}$ & & $\begin{array}{c}0.001 \\
(0.004)\end{array}$ & $\begin{array}{c}0.005 \\
(0.003)\end{array}$ \\
\hline $\begin{array}{l}\text { Years of experience } \\
\text { squared in } 2013\end{array}$ & $\begin{array}{c}606.098 \\
(581.868)\end{array}$ & & $\begin{array}{c}0.000 \\
(0.000)\end{array}$ & $\begin{array}{r}-0.000 \\
(0.000)\end{array}$ \\
\hline \multicolumn{5}{|c|}{ Race: } \\
\hline African American & $\begin{array}{c}0.100 \\
(0.300)\end{array}$ & & $\begin{array}{r}-0.018 \\
(0.043)\end{array}$ & $\begin{array}{r}0.019 \\
(0.042)\end{array}$ \\
\hline $\begin{array}{l}\text { Asian/Pacific } \\
\text { Islander }\end{array}$ & $\begin{array}{c}0.027 \\
(0.161)\end{array}$ & & $\begin{array}{r}-0.114 \\
(0.020)\end{array}$ & $\begin{array}{r}-0.089 \\
(0.033)\end{array}$ \\
\hline Other & $\begin{array}{c}0.085 \\
(0.279)\end{array}$ & & $\begin{array}{r}-0.009 \\
(0.050)\end{array}$ & $\begin{array}{r}-0.022 \\
(0.042)\end{array}$ \\
\hline Hispanic ethnicity & $\begin{array}{c}0.167 \\
(0.373)\end{array}$ & & $\begin{array}{r}-0.030 \\
(0.034)\end{array}$ & $\begin{array}{r}0.013 \\
(0.038)\end{array}$ \\
\hline Female & $\begin{array}{c}0.457 \\
(0.498)\end{array}$ & & $\begin{array}{r}-0.019 \\
(0.024)\end{array}$ & $\begin{array}{r}-0.001 \\
(0.019)\end{array}$ \\
\hline $\begin{array}{l}\text { Self-employed } \\
\quad \text { in } 2013\end{array}$ & $\begin{array}{c}0.104 \\
(0.305)\end{array}$ & & & $\begin{array}{c}0.520 \\
(0.066)\end{array}$ \\
\hline Pseudo $R^{2}$ & & 0.002 & 0.071 & 0.282 \\
\hline Observations & & 1,054 & 1,054 & 1,054 \\
\hline
\end{tabular}

Notes: Sample represents individuals aged 21 years and older as of October-November 2015. Mean of dependent variable is 0.123 . Logistic regressions are weighted using final weights from the October-November 2015 Contingent Worker Survey.

Source: RAND American Life Panel (February-April 2013 Effects of the Financial Crisis and October-November 2015 Contingent Worker Survey).

other workers who were not unemployed a year earlier.

If we estimate the logit model in column 3 using as the outcome variable, in turn, an indicator for each of the four subcategories of alternative work, we find a positive and statistically significant effect of unemployment on subsequently being an independent contractor, on-call worker, or temporary help agency employee, but not for being hired by a contract firm.

Given the difficulties that many older workers encounter in regaining employment after being displaced from a job, we also estimated the models in Table 1 separately for workers age 
40 and older and those less than 40 years old (see supplemental table). We do not find evidence that the likelihood of being subsequently employed in alternative work following a spell of unemployment was significantly greater for older workers than younger workers, however.

Logit estimates for being in an alternative work arrangement in October-November 2015 using the matched RAND-CWS data are presented in Table 2. Similar to Table 1, workers who suffer a spell of unemployment are more likely to be employed subsequently in alternative work, and including more control variables again increases the size of the coefficient on unemployment. Perhaps due to the smaller sample size and large standard errors in the RAND-CWS, the effect of a spell of unemployment 2.5 years prior on subsequent employment in an alternative work arrangement is only statistically significant in the RAND-CWS data after controlling for demographics, educational attainment, and initial self-employment status. Nevertheless, the results using the RAND-CWS data are qualitatively similar to the corresponding estimates from the CPS-CWS data.

Even if we use the largest estimate of the effect of unemployment on the likelihood of being an alternative worker-from the RAND-CWS sample in column 3 of Table 2and assume the effect is causal, the direct effect of higher unemployment would not account for much of the rise in alternative work in the last decade. Consider the following calculation. The BLS "work-experience unemployment rate"which measures the number of workers who report being unemployed at some time during the year as a proportion of the total number of persons who worked or looked for work during the year-averaged 12.7 percent from 2006 to 2015, as compared to 10.1 percent from 1996 to 2005. 5 The 2.6 percentage point (p.p.) decadal rise in unemployment combined with the 17 p.p. higher likelihood of subsequent employment in alternative work by the unemployed would predict only a 0.4 p.p. rise in the share of workers in alternative work, a small share of the 5.1 p.p. increase in the share of workers in alternative work over the decade. If we use the massive 6.9

\footnotetext{
${ }^{5}$ These data are available at https://www.bls.gov/bls/ news-release/home.htm\#WORK (accessed February 14, 2017).
}

p.p. rise in the work-experience unemployment rate caused by the Great Recession (from 9.5 percent in 2007 to 16.4 percent in 2009), we would only predict a 1.2 p.p. rise in the alternative work share.

Although the work-experience unemployment rate understates the fraction of workers who experienced a spell of unemployment over a period longer than a year, we conclude that it is unlikely that the decadal differences in the incidence of unemployment can explain much of the rise in alternative work absent large spillover effects.

\section{Time-Series Evidence}

We next examine US aggregate annual time series data on the evolution of two indicators of alternative work arrangements-Schedule C filers and temporary help services employmentto further explore the role of trend versus cyclical factors in the rise of alternative work arrangements. The share of workers with Schedule C income (an indicator for the self-employed and independent contractors) increased from 8.7 percent in 1979 to 12.3 percent in 1990 to 14.9 percent in 2005 to 16.5 percent in 2014. The temporary help services share of total employment increased from 1.0 percent in 1990 to 1.8 percent in 2005 to 1.9 percent in 2015.6

A simple time-series regression of the Schedule C share of employment on a linear time trend and the unemployment rate from 1979 to 2014 shows that the Schedule C employment share is counter-cyclical (with a significant coefficient of 0.098 on the unemployment rate) and shows a strongly significant upward trend of 0.2 p.p. per year. The implication is that almost the entire rise in Schedule C employment since 1979 reflects trend factors. An analogous

\footnotetext{
${ }^{6}$ The number of Schedule C filers is from Table 1.3 of the Statistics of Income (https://www.irs.gov/uac/soitax-stats-individual-statistical-tables-by-filing-status\#_ grp1). Temporary help services employment (BLS series CEU6056132001) is only available since 1990 (www. bls.gov). For consistency, we use CPS employment as the denominator for both the Schedule $\mathrm{C}$ and temporary help employment share series. The rise in temporary help services employment using the BLS establishment survey data from 2005 to 2015 is much smaller than the rise in the share of workers indicating their main job is with a temporary help agency from 0.9 percent in 2005 to 1.6 percent in 2015 in the CWS surveys (Katz and Krueger 2016).
} 
regression for 1990 to 2015 indicates that temporary help employment, in contrast, is procyclical (with a significant coefficient of -0.120 on the unemployment rate), but it also has a strong upward trend (of 0.035 p.p. per year). The sum of Schedule C and temporary help services employment is counter-cyclical for the period 1990 to 2014, with a significant unemployment coefficient of 0.084 and a positive trend of 0.2 p.p. per year. The combined regression implies that the rise in unemployment from 5.1 percent in 2005 to 6.2 percent in 2014 in the aftermath of the Great Recession can explain only about 5 percent of the 1.7 p.p. rise in Schedule C plus temporary help employment share from 2005 to 2014.

\section{Conclusion}

The share of the US workforce in alternative work arrangements, especially self-employment and contract work, has increased substantially in recent decades. Micro longitudinal analyses and macro time-series evidence show that weak labor market conditions and a high share of workers experiencing unemployment are associated with an increase in nontraditional work. But the magnitude of the impact of cyclical labor market conditions is not large enough to explain much of the shift from traditional to alternative work arrangements. Changes in the demographic composition of the workforce also explain only a modest rise in alternative work (Katz and Krueger 2016). The increase in alternative work arrangements from around 10 percent of the workforce in the 1990s to
16 percent today is probably largely driven by secular factors associated with rising inequality and technological changes making it easier to standardize and contract out work. A surge in the contracting out of formerly in-house work and the increased use of temporary help agencies are indicators of a broader fissuring of US workplaces, a rise in the segregation of similarly skilled workers across employers, and an increase in the positive assortative matching of high-wage workers and high-wage employers (Song et al. 2015). Increased demand for flexible work arrangements and a better work-life balance also may have contributed to the growth in alternative work arrangements.

\section{REFERENCES}

Katz, Lawrence F., and Alan B. Krueger. 2016. "The Rise and Nature of Alternative Work Arrangements in the United States, 19952015." National Bureau of Economic Research Working Paper 22667.

- Rothstein, Jesse. 2011. "Unemployment Insurance and Job Search in the Great Recession." Brookings Papers on Economic Activity (Fall): 143-213.

Song, Jae, David J. Price, Fatih Guvenen, Nicholas Bloom, and Till von Wachter. 2016. "Firming up Inequality." fguvenendotcom.files. wordpress.com/2014/04/fui_22oct2016_final_ qje_submit.pdf.

Weil, David. 2014. The Fissured Workplace: Why Work Became So Bad for So Many and What Can Be Done to Improve It. Cambridge, MA: Harvard University Press. 


\title{
"The Role of Unemployment in the Rise in Alternative Work Arrangements"
}

\author{
Lawrence F. Katz and Alan B. Krueger
}

Online Appendix

\begin{tabular}{|c|c|c|c|c|c|c|c|c|c|c|c|c|}
\hline & \multicolumn{12}{|c|}{$\begin{array}{l}\text { Table 2(a) } \\
\text { Marginal Effects From Logit Model of Being in Alternative Work Arrangements Conditional on February } 2004 \text { Characteristics }\end{array}$} \\
\hline & \multirow{2}{*}{\multicolumn{12}{|c|}{$\begin{array}{cccc} & \text { Dependent Variable: Indicator Variable for Alternative Work Arrangement in February } 2005 \\
16 \text { Years \& Over } & 16-39 \text { Years } & 40 \mathrm{Y}\end{array}$}} \\
\hline & & & & & & & \multicolumn{2}{|c|}{$16-39$ Years } & \multicolumn{2}{|c|}{40 Years \& Over } & & \\
\hline & \multicolumn{4}{|c|}{16 Years \& Over } & Mean & & & & Mean & & & \\
\hline & Std Dev. & (1) & (2) & (3) & Std Dev. & (4) & (5) & (6) & Std Dev. & (7) & (8) & (9) \\
\hline \multirow[t]{2}{*}{ Unenpbyed in February 2004} & 0.029 & $0.075^{\text {kt* }}$ & 0.098 kt* & 0.121 k*t & 0.042 & $0.090 \ldots$ & $0.099 \ldots$ & $0.123 \ldots$ & 0.019 & $0.070^{* *}$ & 0.083 ** & $0.110^{* 6 * t}$ \\
\hline & $(0.168)$ & $(0.023)$ & $(0.025)$ & $(0.024)$ & $(0.202)$ & $(0.030)$ & $(0.032)$ & $(0.030)$ & $(0.138)$ & $(0.035)$ & $(0.036)$ & $(0.037)$ \\
\hline \multirow[t]{2}{*}{ Years of Education } & 13.726 & & $0.003 *$ & -0.000 & 13.518 & & -0.001 & -0.003 & 13.876 & & 0.005 ats & 0.002 \\
\hline & $(2.661)$ & & $(0.001)$ & $(0.001)$ & $(2510)$ & & $(0.002)$ & $(0.002)$ & $(2.755)$ & & $(0.002)$ & $(0.002)$ \\
\hline \multirow[t]{2}{*}{ Years of Experience } & 22.241 & & $0.002 * \cdots$ & 0.000 & 10.544 & & $0.008 \ldots$ & $0.006 \ldots$ & 30.650 & & -0.001 & -0.000 \\
\hline & (12.344) & & $(0.001)$ & $(0.001)$ & $(6.290)$ & & $(0.003)$ & $(0.002)$ & $(8.025)$ & & $(0.003)$ & $(0.003)$ \\
\hline Years of Experience Squared & $\begin{array}{r}647.020 \\
(601.098)\end{array}$ & & $\begin{array}{l}-0.000 \\
(0.000)\end{array}$ & $\begin{array}{r}0.000 \\
(0.000)\end{array}$ & $\begin{array}{r}150.731 \\
(139.016)\end{array}$ & & $\begin{array}{r}-0.000 \\
(0.000)\end{array}$ & $\begin{array}{l}-0.000 \\
(0.000)\end{array}$ & $\begin{array}{l}1,003.821 \\
(550.274)\end{array}$ & & $\begin{array}{r}0.000 \\
(0.000)\end{array}$ & $\begin{array}{r}0.000 \\
(0.000)\end{array}$ \\
\hline \multicolumn{13}{|l|}{ Race: } \\
\hline Africal-American & $\begin{array}{r}0.087 \\
(0.281)\end{array}$ & & $\begin{array}{l}-0.036 \\
(0.010)\end{array}$ & $\begin{array}{l}-0.013 \\
(0.011)\end{array}$ & $\begin{array}{r}0.091 \\
(0.287)\end{array}$ & & $\begin{array}{l}-0.031 \ldots \\
(0.013)\end{array}$ & $\begin{array}{l}-0.009 \\
(0.015)\end{array}$ & $\begin{array}{r}0.084 \\
(0.277)\end{array}$ & & $\begin{array}{l}-0.042 \\
(0.013)\end{array}$ & $\begin{array}{l}-0.017 \\
(0.015)\end{array}$ \\
\hline \multirow[t]{2}{*}{ AsianPacific Islander } & 0.049 & & $-0.024^{*}$ & $-0.030 * * *$ & 0.059 & & $-0.034 \ldots$ & $-0.028 *$ & 0.043 & & -0.011 & $-0.031 *$ \\
\hline & $(0.217)$ & & $(0.014)$ & $(0.011)$ & $(0.235)$ & & $(0.015)$ & $(0.016)$ & $(0.202)$ & & $(0.022)$ & $(0.015)$ \\
\hline Other & $\begin{array}{r}0.018 \\
(0.133)\end{array}$ & & $\begin{array}{r}0.024 \\
(0.023)\end{array}$ & $\begin{array}{r}0.021 \\
(0.018)\end{array}$ & $\begin{array}{r}0.021 \\
(0.144)\end{array}$ & & $\begin{array}{r}0.003 \\
(0.029)\end{array}$ & $\begin{array}{r}0.010 \\
(0.029)\end{array}$ & $\begin{array}{r}0.016 \\
(0.125)\end{array}$ & & $\begin{array}{r}0.039 \\
(0.034)\end{array}$ & $\begin{array}{r}0.027 \\
(0.023)\end{array}$ \\
\hline \multirow[t]{2}{*}{ Hispanic Etmixity } & 0.101 & & $-0.030 * \cdots$ & -0.009 & 0.132 & & $-0.039 \ldots$ & $-0.026 \ldots$ & 0.078 & & -0.021 & 0.013 \\
\hline & $(0.301)$ & & $(0.010)$ & $(0.010)$ & $(0.339)$ & & $(0.011)$ & $(0.012)$ & $(0.268)$ & & $(0.016)$ & $(0.017)$ \\
\hline \multirow[t]{2}{*}{ Female } & 0.468 & & $-0.025 \cdots$ & -0.002 & 0.461 & & $-0.028 \ldots$ & $-0.018 \ldots$ & 0.473 & & $-0.021 * t$ & 0.011 \\
\hline & $(0.499)$ & & $(0.006)$ & $(0.005)$ & $(0.499)$ & & $(0.008)$ & $(0.008)$ & $(0.499)$ & & $(0.008)$ & $(0.007)$ \\
\hline \multirow[t]{2}{*}{ Self-Enpbyed } & 0.108 & & & $0.430 * * *$ & 0.065 & & & $0.409 \ldots$ & 0.140 & & & $0.439 * * *$ \\
\hline & $(0.311)$ & & & $(0.016)$ & $(0.246)$ & & & $(0.031)$ & $(0.347)$ & & & $(0.018)$ \\
\hline \multicolumn{13}{|l|}{ Dependent Variabl: } \\
\hline Mean & & 0.099 & 0.099 & 0.099 & & 0.081 & 0.081 & 0.081 & & 0.113 & 0.113 & 0.113 \\
\hline Standard Dervation & & 0.299 & 0.299 & 0.299 & & 0.273 & 0.273 & 0.273 & & 0.316 & 0.316 & 0.316 \\
\hline Pseudo R-Squared & & 0.002 & 0.021 & 0.213 & & 0.006 & 0.031 & 0.172 & & 0.001 & 0.014 & 0.237 \\
\hline Number of Obsernations & & 13,387 & 13,387 & 13,387 & & 5,250 & 5,250 & 5,250 & & 8,137 & 8,137 & 8,137 \\
\hline
\end{tabular}

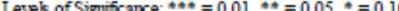

Note: Logistic regressious are weighted using fmal weights from February 2004 Currert Population Survey.

Source: Currerr Population Survey (February 2004 Basic Monthly Data and February 2005 Courngent Wort Supplement) 